\title{
Forskningsløft for et lite fag
}

\author{
Mer samarbeid, klare mål og god personalpolitikk må til for å styrke norsk dermatologisk forskning.
}

Det medisinske fakultet i Oslo er uten professor i hudsykdommer, Trondheim og Tromsø har vært uten professor lenge, og om få år kan dette også gjelde Bergen. Siden 2000 har seks leger fra hudavdelingen i Oslo tatt doktorgrad, men alle har senere gått over i annen virksomhet, de fleste til privatpraksis. Ved de andre hudavdelingene har forskningsaktiviteten vært svakere, og også her preges bildet av at forskningskompetente hudleger slutter. Målt i antall dermatologiske vitenskapelige artikler registrert i Medline ligger Norge svært langt bak både Danmark, Sverige og Finland (1).

Årsakene til denne situasjonen er mange og sammensatte. Fagmiljøene har lagt for liten vekt på forskning, sykehusene har i for stor grad latt pasientbehandling gå foran forskning, fakultetene har vært lite aktive, og oppfølgingen etter avlagt doktorgrad har vært svak (2). Legeforskere har dårlig lønn, og mange leger velger bort forskning av hensyn til egen fritid, familie og inntekt. Samlet ligger all klinisk medisinsk forskning i Norge bak de andre nordiske landene (3). Historiske og kulturelle faktorer må antas å ha betydning (1).

\section{Felles ansvar}

Et åpent og godt samarbeid mellom fagmiljøene, universitetssykehusene og fakultetene er avgjørende for å få til et løft for norsk dermatologisk forskning. Norsk dermatologisk selskap fremla for 15 år siden en handlingsplan for å styrke fag og forskning (4), men planen fikk lite gjennomslag (5). Hvert år deler foreningen ut forskningsstipendier og samler avdelingslederne fra universitetssykehusene for å diskutere felles problemer. I 2007 etablerte foreningen et forskningsutvalg, som arrangerer forskerseminarer, utgir medlemsblad og deler ut pris for årets beste forskningsartikkel. Hudleger samarbeider i ulike faglige nettverk. Flere leger er nå i ulike faser av et doktorgradsprosjekt, deriblant seks i Oslo og fem i Trondheim. Det er optimisme å spore.

Men det er fakultetene - sammen med sykehusene og andre forskningsorganisasjoner - som har tilsettingsmyndighet, lønnsmidler og styringsrett over forskernes arbeidsbetingelser. I den akademiske verden er imidlertid beslutningsprosessene omstendelige, budsjettene stramme og handlingsrommet trangt. Gjeldende forskningspolitikk om å prioritere forskningsen- heter som lykkes - en politikk som har mye for seg - må ikke føre til at små fag som strever blir glemt.

Det er positivt at de to hudavdelingene i Oslo ble slått sammen i 2007, og at hudleger med akademisk kompetanse uten sykehusstilling ansettes i deltids universitetsstilling. En intern arbeidsgruppe ved Oslo universitetssykehus, opprettet i 2009 av fakultet og sykehus i fellesskap, påpekte to hovedproblemer for sykehusets hudavdeling: at leger med forskningskompetanse forsvinner, og at forskningen er spredt på for mange felter. Gruppen foreslo en rekke tiltak.

Dette var en god start for et forskningsløft. Få måneder senere ble hudavdelingen degradert til en seksjon og lagt inn i en større avdeling, som fikk en avdelingsleder uten medisinsk, dermatologisk eller vitenskapelig bakgrunn. Slike organisatoriske grep gir lengre beslutningslinjer oppover i systemet, skaper misnøye og frustrasjon blant ansatte og vil tolkes som en nedprioritering av dermatologisk forskning. En fusjon med revmatologi og infeksjonsmedisin kan begrunnes med en faglig synergieffekt, men det vil i så fall innebære en ytterligere spredning $\mathrm{i}$ forskningstemaer.

\section{Mer og bedre forskning}

Etter mitt skjønn er det tre forhold som er av særlig betydning for å styrke dermatologisk forskning: Mer samarbeid, klare mål og god personalpolitikk.

Norske hudavdelinger er små og må samarbeide enda mer enn i dag - seg imellom og med andre. Forskningsprosjekter må (fortsatt) etableres i samarbeid med andre fagområder, særlig laboratoriefag, men uten for stor spredning av temaer. Kontakten med utenlandske fagmiljøer, spesielt danske og svenske, må styrkes. Leger med forskerpotensial må identifiseres og motiveres tidlig. Forskning må tillegges større vekt ved tilsettinger og andre viktige beslutninger. Det må settes opp tydelige krav og mål for sykehuslegers faglige virksomhet. Ambisjonsnivået må være høyt nok, men ikke urealistisk. Bedre lønn er svært viktig, men like mye god veiledning. Hudleger med doktorgrad må stimuleres til å fortsette med forskning, veiledning og annen akademisk virksomhet. Da er det behov for fleksible stillingsordninger, noe jeg tror vil tvinge seg frem etter hvert.

Ved et universitetssykehus må ledelsen på alle nivåer være like opptatt av forskning som av effektiv sykehusdrift. Mer og bedre forskning er en utfordring for både norsk dermatologi og norsk medisin.

\section{Petter Gjersvik}

petjense@online.no

Observatorie terrasse $7 \mathrm{C}$

0270 Oslo

Oppgitte interessekonflikter: Forfatteren er medlem av forskningsutvalget i Norsk dermatologisk selskap, førsteamanuensis i hudsykdommer ved Universitetet i Oslo og medisinsk redaktør i Tidsskriftet. Han driver spesialistpraksis på deltid.

Litteratur

1. Gjersvik P, Nylenna M, Jemec GBE et al. Dermatologic research in the Nordic countries 1989-2008 - a bibliometric study. Int J Dermatol 2010; akseptert for publisering.

2. Rustad L. Dermatologi - en ikke-akademisk spesialitet? Masteravhandling. Oslo: Universitetet i Oslo, 2007.

3. Evaluation of clinical, epidemiological, public health, health-related and psychological research in Norway. Clinical research. Oslo: Norges forskningsråd, 2004. www.forskningsradet.no/en/ Evaluations/1138882276154 (29.1.2010)

4. Dermatovenerologi i Norge mot år 2010. Plan for utviklingen av faget. Oslo: Norsk dermatologisk selskap, 1995.

5. Lützow-Holm C. Challenges for Norwegian dermato-venereology towards the year 2020. Forum for Nordic Dermato-Venereology 2000; 5, nr. 4: 5-8. http://forum.medicaljournals.se/article/ 20000504005 (29.1.2010).

Manuskriptet ble mottatt 15.2. 2010 og godkjent 19.3. 2010. Medisinsk redaktør Anne Kveim Lie. 